\title{
In situ chemical monitoring and imaging of contents within microfluidic devices having a porous membrane wall using liquid microjunction surface sampling probe mass spectrometry.
}

\section{SUPPORTING INFORMATION}

John F. Cahill ${ }^{1, *}$, Muneeba Khalid ${ }^{1}$, Scott T. Retterer ${ }^{1}$, Courtney L. Walton ${ }^{1}$, Vilmos Kertesz ${ }^{1}$

${ }^{1}$ Oak Ridge National Laboratory, Oak Ridge, TN 37831-6131, USA

*Corresponding Author:

John F. Cahill

Mass Spectrometry and Laser Spectroscopy Group

Chemical Sciences Division

Oak Ridge National Laboratory, Oak Ridge, TN 37831-6131

E-mail: cahilljf@ornl.gov

Phone: 865-574-4878 


\section{Design of the flow cells}

A schematic of the microfluidic device preparation is shown in Figure S1.

Design of the single channel flow cell. The single channel flow cell microfluidic device design consisted of $20 \mathrm{~mm}$ long $\times 0.5 \mathrm{~mm}$ wide $\times 70 \pm 2 \mu \mathrm{m}$ high single channel with circular inlet and outlet of same height and $1 \mathrm{~mm}$ diameter at the ends of the channel.

Design of the $Y$ shaped flow cell. The Y-shaped flow cell featuring a $20 \mathrm{~mm}$ long $\times 1 \mathrm{~mm}$ wide $\times 160 \pm 5 \mu \mathrm{m}$ high single cell bifurcating into $10 \mathrm{~mm}$ long $\times 0.75 \mathrm{~mm}$ wide $\times 160 \pm 5 \mu \mathrm{m}$ high legs to create a $\mathrm{Y}$ shape was designed to understand the exchange and interaction of biocomponents within the system. Two circular inlets, $1 \mathrm{~mm}$ in diameter, were designed at the ends of the two legs, whereas an outlet was designed at the end of the single leg of Y shaped mixing flow cell (Figure 3).

Design of the mixing flow cell This mixing flow cell featured two inlets joined in a Y shape, with each inlets leg $9 \mathrm{~mm}$ long $\times 1 \mathrm{~mm}$ wide. After joining, the channel forms a zig-zag M shaped leg $34 \mathrm{~mm}$ long $\times 1-2 \mathrm{~mm}$ wide. Smaller $0.25 \mathrm{~mm}$ channels traverse the M shape shown in Figure 6 . The height of the flow channels was $180 \pm 4 \mu \mathrm{m}$ with inlets and an outlet of $1 \mathrm{~mm}$ in diameter. Total length of the channel was $40 \mathrm{~mm}$.

\section{Calculation of limit of detection from LMJ-SSP-MS and extraction parameters}

Caffeine concentration determined by LMJ-SSP-MS $\left(C_{M S}\right)$ can be used to calculate the volumetric flow rate of extraction $\left(Q_{\text {Extraction }}\right)$ using the formula for calculating the analyte dilution factor $(D)$ by the LMJ-SSP technique (Eq (1)):

$$
\text { Eq 1: } \quad D=\frac{Q_{\text {Extraction }}}{Q_{L M J-S S P}+Q_{\text {Extraction }}}=\frac{C_{M S}}{C_{\text {Solution }}}
$$

Where $C_{\text {Solution }}$ is the analyte concentration in the microfluidic device and $Q_{L M J-S S P}$ is the volumetric flowrate in the LMJ-SSP. Rearrangement of Eq (1) yields:

$$
\text { Eq 2: } \quad Q_{\text {Extract }}=\frac{\left(\frac{C_{M S} \cdot Q_{L M J-S S P}}{C_{\text {Solution }}}\right)}{\left(1-\frac{C_{M S}}{C_{\text {Solution }}}\right)}
$$

As a consequence of Eq 1 and 2, the sensitivity of the LMJ-SSP approach is directly related to the amount of fluid extracted and the flow settings used in the probe. The LOD for any particular compound in the fluid of the microfluidic device $\left(C_{\text {Solution,LOD }}\right)$ can be estimated using Eq 3:

$$
\text { Eq 3: } \quad C_{\text {Solution }, L O D}=\frac{Q_{\text {Extraction }} \cdot C_{M S, L O D}}{Q_{L M J-S S P}+Q_{\text {Extraction }}}
$$

Where $C_{M S, L O D}$ is the empirically determined LOD of mass spectrometric detection for that analyte and $Q_{L M J-S S P}$ is the volumetric flow rate used for LMJ-SSP-MS. In this work, the LOD 
for caffeine using the mass spectrometer in the present configuration (Figure S2) was $1 \mathrm{nM}$ indicating that a caffeine concentration $>253 \mathrm{nM}$ is needed in the flow cell in order to be detected (assuming $Q_{\text {Extraction }}=1 \mu \mathrm{L} / \mathrm{min}$ and $Q_{L M J-S S P}=151 \mu \mathrm{L} / \mathrm{min}$ ).

\section{Continuous Rastering Across a Single Channel}

To demonstrate reproducible and repeated sampling across the porous membrane surface of the channel the LMJ-SSP was continuously rastered forward and backward 27 times in 15 min across the same location of the channel at a rate of $0.1 \mathrm{~mm} / \mathrm{s}$ (Figure S3a). Effectively, these scans demonstrate periodic monitoring of the fluid channel over several minutes. A $1.83 \mu \mathrm{M}$ caffeine solution was continuously flowed through the flow cell at a rate of $10 \mu \mathrm{L} / \mathrm{min}$. Transects across the channel result in a Gaussian-like signal profile that remained consistent for all 27 replicate scans. Average caffeine signal normalized to caffeine- $\mathrm{d}_{3}$ of the forward and backward transects are shown in Figure S3b. A reproducible difference in signal intensity was observed when rastering in the forward versus the backward direction across the single lane (Figure S3b) for this specific experiment. The reason for this is likely due to the reduced time for fluid replenishment in the channel after sampling in the backward direction (13.5 s) relative to the forward direction (19.7 s). To avoid this issue all subsequent imaging experiments were conducted while rastering in one direction.

\section{LMJ-SSP MS imaging of propranolol and caffeine in mixing flow cell}

Chemical images of an unreactive mixture flowed through the two-channel mixing flow cell are shown in Figure S5. Propranolol (15 $\mu \mathrm{L} / \mathrm{min}$ of $1.83 \mu \mathrm{M}$ (a.q.)) was flowed through input channel \#1 and caffeine was flowed (15 $\mu \mathrm{L} / \mathrm{min}$ of $1.83 \mu \mathrm{M}$ (a.q.)) from input channel \#2. The LMJ-SSP was rastered across the flow cell at $0.1 \mathrm{~mm} / \mathrm{s}$, with $0.5 \mathrm{~mm}$ spacing between lanes for 41 lanes. The image comprised an $8 \mathrm{~mm} \times 20 \mathrm{~mm}$ surface area and was extracted to form 0.1 $\mathrm{mm} \times 0.5 \mathrm{~mm}$ pixel size. 
Table S1: Average mass spectrometric signal of caffeine- $\mathrm{d}_{3}$ in water outflows collected from 5$15 \mu \mathrm{L} / \mathrm{min}$ flow cell flow rates with LMJ-SSP sampling. LMJ-SSP solvent was the only source of caffeine- $d_{3}$. Blank data was acquired with a water flowrate of $10 \mu \mathrm{L} / \mathrm{min}$ without LMJ-SSP sampling. LMJ-SSP sampling parameters were LMJ-SSP flow rate $=150 \mu \mathrm{L} / \mathrm{min}$, LMJ-SSP-tosurface distance $=20 \mu \mathrm{m}$ and membrane pore size $=0.4 \mu \mathrm{m}$.

\begin{tabular}{c|ccc} 
Sample & $\begin{array}{c}\text { Average Intensity } \\
(m / z \text { 198 })\end{array}$ & Std. Dev. & RSD \\
\hline Blank & 11457 & 2580 & $23 \%$ \\
$5 \mu \mathrm{L} / \mathrm{min}$ & 10701 & 1055 & $10 \%$ \\
$10 \mu \mathrm{L} / \mathrm{min}$ & 10936 & 1935 & $18 \%$ \\
$15 \mu \mathrm{L} / \mathrm{min}$ & 10604 & 1883 & $18 \%$
\end{tabular}


Table S2: Measured flows through the membrane and into the LMJ at different LMJ-to-membrane distances. Flows were measured by outflow mass and by quantitation of caffeine simultaneously. LMJ-SSP sampling parameters were LMJ-SSP flow rate $=150 \mu \mathrm{L} / \mathrm{min}$, membrane pore size $=0.4$ $\mu \mathrm{m}$, and flow cell flow rate $=10 \mu \mathrm{L} / \mathrm{min}$.

\begin{tabular}{c|cc|cc|c}
$\mathrm{Z}(\mu \mathrm{m})$ & $\begin{array}{c}\text { Flow Extracted } \\
(\mu \mathrm{L} / \mathrm{min})[\text { By Weight] }\end{array}$ & $\begin{array}{c}\text { Std. } \\
\text { Dev. }\end{array}$ & $\begin{array}{c}\text { Flow Extracted } \\
(\mu \mathrm{L} / \mathrm{min})[\text { By MS] }\end{array}$ & $\begin{array}{c}\text { Std. } \\
\text { Dev. }\end{array}$ & \% of Flow \\
\hline 0 & 2.93 & 0.45 & 2.87 & 0.36 & $31 \%$ \\
10 & 2.64 & 0.09 & 2.63 & 0.09 & $28 \%$ \\
20 & 2.09 & 0.36 & 2.36 & 0.30 & $22 \%$ \\
30 & 1.52 & 0.12 & 1.87 & 0.18 & $16 \%$ \\
40 & 0.75 & 0.33 & 0.97 & 0.18 & $8 \%$ \\
50 & 0.55 & 0.15 & 0.64 & 0.13 & $6 \%$ \\
60 & 0.47 & 0.07 & 0.44 & 0.02 & $5 \%$
\end{tabular}


Table S3: Measured flows through the membrane and into the LMJ using several LMJ-SSP solvent flow rates. Flows were measured by quantitation of caffeine. LMJ-SSP sampling parameters were LMJ-SSP-to-surface distance $=20 \mu \mathrm{m}$, membrane pore size $=0.4 \mu \mathrm{m}$, and flow cell flow rate $=10 \mu \mathrm{L} / \mathrm{min}$.

\begin{tabular}{c|cc|c}
$\begin{array}{c}\text { Flow Rate } \\
(\mu \mathrm{L} / \mathrm{min})\end{array}$ & $\begin{array}{c}\text { Volume Extracted }(\mu \mathrm{L} / \mathrm{min}) \\
{[\text { By MS] }}\end{array}$ & Std. Dev. & \% of Flow \\
\hline 75 & 1.9788 & 0.0097 & $20 \%$ \\
100 & 1.4854 & 0.0071 & $15 \%$ \\
125 & 0.8691 & 0.0018 & $9 \%$ \\
150 & 0.4333 & 0.0006 & $4 \%$ \\
175 & 0.3132 & 0.0004 & $3 \%$
\end{tabular}


Table S4: Measured flows through the membrane and into the LMJ using PETE membranes with several pore diameters. Flows were measured by outflow mass and by quantitation of caffeine simultaneously. LMJ-SSP sampling parameters were LMJ-SSP-to-surface distance $=20 \mu \mathrm{m}$, LMJ$\mathrm{SSP}=150 \mu \mathrm{L} / \mathrm{min}$ and flow cell flow rate $=10 \mu \mathrm{L} / \mathrm{min}$.

\begin{tabular}{c|cc|cc|c}
$\begin{array}{c}\text { Pore } \\
\text { Size }\end{array}$ & $\begin{array}{c}\text { Volume Extracted } \\
(\mu \mathrm{L} / \mathrm{min})[\text { By Weight] }\end{array}$ & $\begin{array}{c}\text { Std. } \\
\text { Dev. }\end{array}$ & $\begin{array}{c}\text { Volume Extracted } \\
(\mu \mathrm{L} / \mathrm{min})[\mathrm{By} \mathrm{MS}]\end{array}$ & $\begin{array}{c}\text { Std. } \\
\text { Dev. }\end{array}$ & $\begin{array}{c}\% \text { of } \\
\text { Flow }\end{array}$ \\
\hline 0.1 & 0.10 & 0.05 & 0.108 & 0.004 & $1 \%$ \\
0.2 & 1.24 & 0.38 & 1.21 & 0.18 & $13 \%$ \\
0.4 & 2.93 & 0.45 & 2.87 & 0.36 & $31 \%$ \\
5.0 & 9.24 & 0.47 & 9.86 & 0.13 & $97 \%$
\end{tabular}


Table S5: Measured flows through the membrane and into the LMJ with different flow rates in the microfluidic cell. Flows were measured by outflow mass and by quantitation of caffeine simultaneously. LMJ-SSP sampling parameters were LMJ-SSP-to-surface distance $=20 \mu \mathrm{m}$, LMJ$\mathrm{SSP}=150 \mu \mathrm{L} / \mathrm{min}$ and membrane pore size $=0.4 \mu \mathrm{m}$.

\begin{tabular}{c|cc|cc|c}
$\begin{array}{c}\text { Flow Rate } \\
(\mu \mathrm{L} / \mathrm{min})\end{array}$ & $\begin{array}{c}\text { Volume Extracted } \\
(\mu \mathrm{L} / \mathrm{min})[\mathrm{By} \text { Weight] }\end{array}$ & $\begin{array}{c}\text { Std. } \\
\text { Dev. }\end{array}$ & $\begin{array}{c}\text { Volume Extracted } \\
(\mu \mathrm{L} / \mathrm{min})[\mathrm{By} \mathrm{MS}]\end{array}$ & $\begin{array}{c}\text { Std. } \\
\text { Dev. }\end{array}$ & $\begin{array}{c}\% \text { of } \\
\text { Flow }\end{array}$ \\
\hline 5 & 0.80 & 0.14 & 0.93 & 0.23 & $25 \%$ \\
10 & 1.14 & 0.23 & 1.25 & 0.14 & $17 \%$ \\
15 & 0.84 & 0.05 & 0.97 & 0.05 & $10 \%$
\end{tabular}


a)

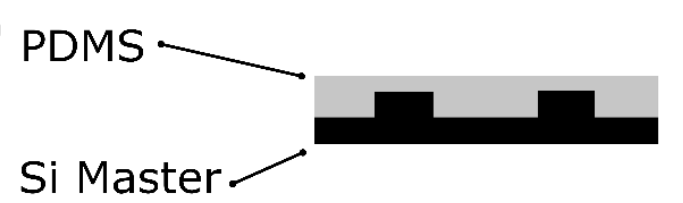

b) Negative PDMS Mold
Thin PDMS Layer on Si wafer

c)

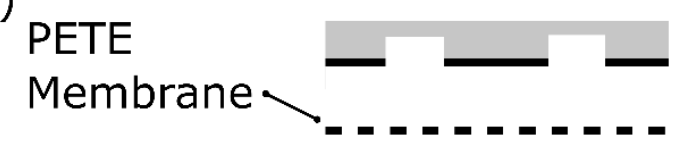

d) Completed Device

Figure S1: Schematic of microfluidic device fabrication showing (a) formation of PDMS base, (b) addition of inked PDMS layer, (c) attachment of PETE membrane, and (d) completed device. 


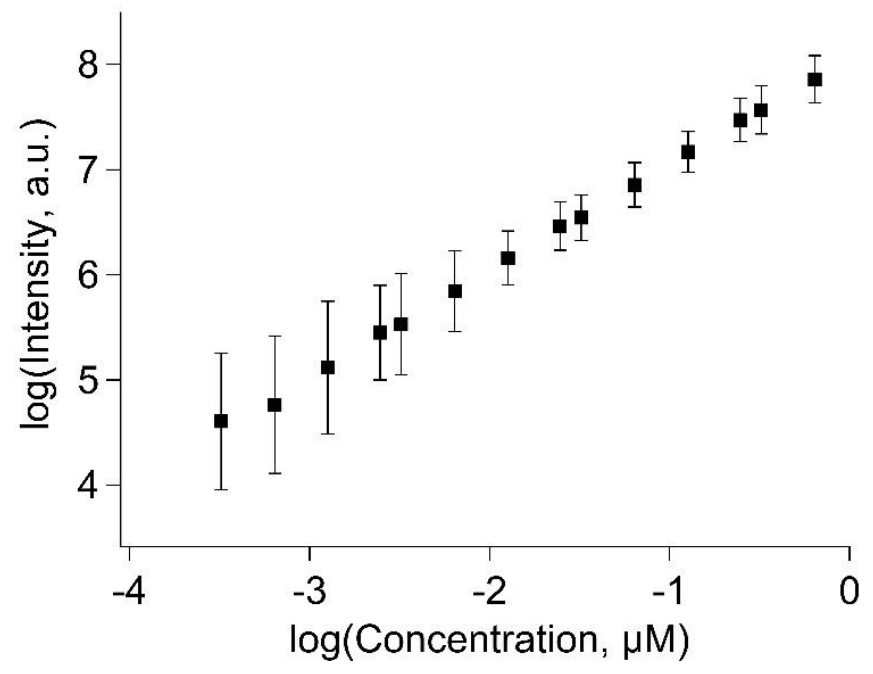

Figure S2: Calibration curve of caffeine. 

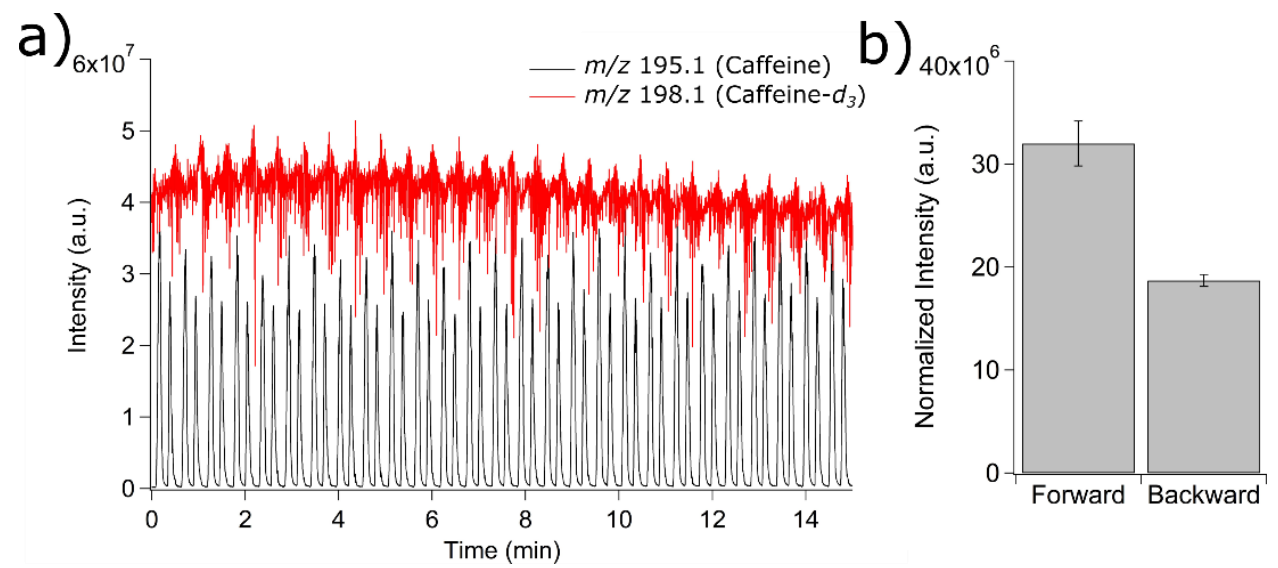

Figure S3: (a) Extracted ion chronograms of $m / z, 195.1$ (black) and $m / z, 198.1$ (red) corresponding to caffeine and caffeine- $\mathrm{d}_{3}$ signals, respectively. (b) Average integrated signal of transects acquired in the forward and backward directions. 


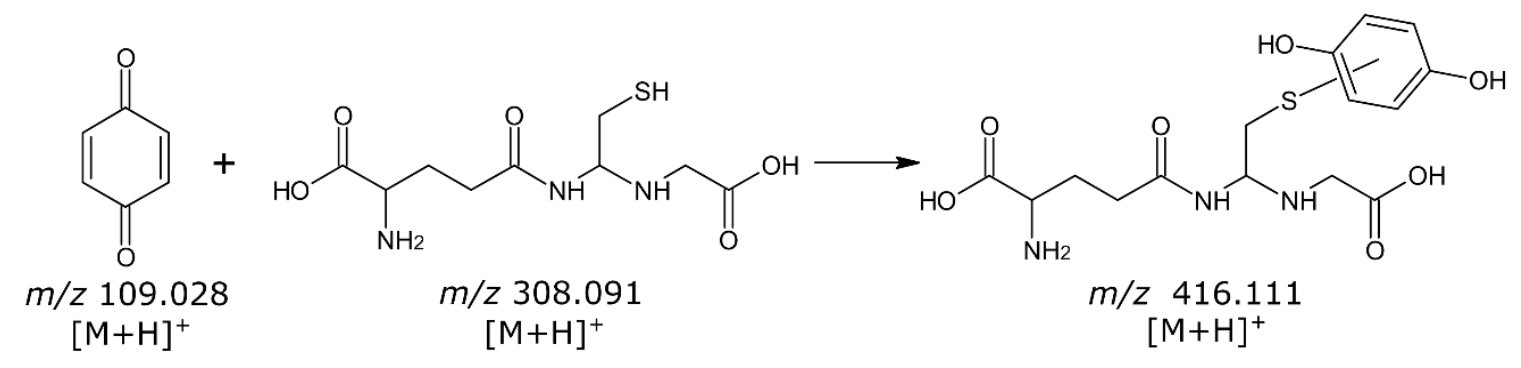

Figure S4: The reaction of p-benzoquinone $\left(\mathrm{m} / \mathrm{z} 109.028[\mathrm{M}+\mathrm{H}]^{+}\right)$with L-glutathione $(\mathrm{m} / \mathrm{z}$ $\left.308.091[\mathrm{M}+\mathrm{H}]^{+}\right)$to form a quinone-tagged glutathione $\left(\mathrm{m} / z 416.111[\mathrm{M}+\mathrm{H}]^{+}\right)$. 
a)

b)

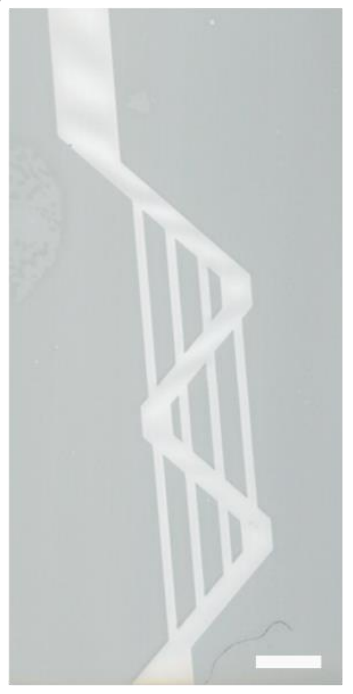

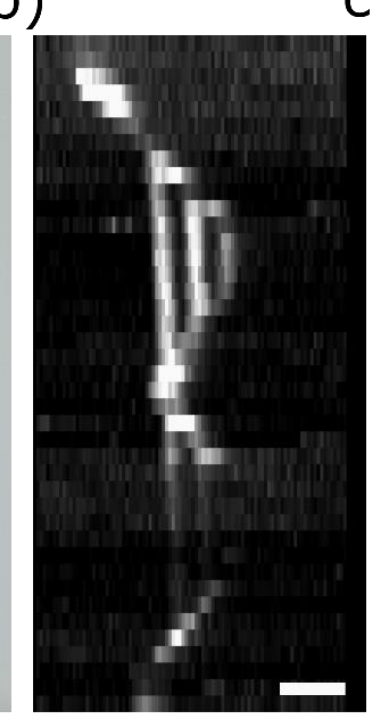

C)

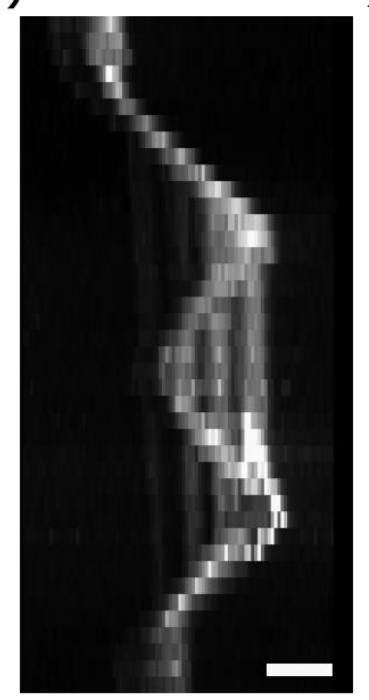

d)

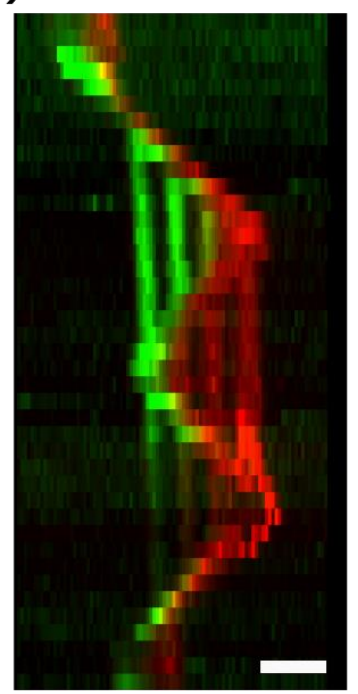

Figure S5: (a) Optical image of the microfluidic flow cell with two-channel mixer design. MS image of (b) caffeine $(\mathrm{m} / \mathrm{z}$ 138.1, green) and (c) propranolol $(\mathrm{m} / \mathrm{z}$ 116.1) fragment ions. (d) Combined MS image of caffeine (green) and propranolol (red). Scalebar represents $2 \mathrm{~mm}$. 